\title{
For 'the present and future happiness of my dear Pupils': \\ The Astronomical and Educational Legacy of Margaret Bryan
}

\section{Voula Saridakis}

\begin{abstract}
Jane Austen wrote in her novel Emma that boarding schools were 'where a reasonable quantity of accomplishments were sold at a reasonable price, and where girls might be sent to be out of the way, and scramble themselves into a little education, without any danger of coming back prodigies'. Austen's contemporary, astronomer and natural philosopher Margaret Bryan, would have vehemently disagreed with such a dismissive assessment of her own schools. Bryan, whose image (along with her two daughters) appears on the frontispiece of her work A Compendious System of Astronomy (1797), taught astronomy and natural philosophy to girls at her school in Blackheath, London from 1795 to 1806 , and opened another school in central London in 1815. Her schools and books gave a general grounding in astronomy and physics to young women interested in the sciences. This paper assesses the astronomical and educational tradition passed down by Bryan. Despite the difficulties faced by British women pursuing astronomical education and employment throughout the nineteenth century, the increasing number of women attending astronomy classes, and their growing participation in lectures, organizations, and expeditions, are a testament to Bryan's legacy.
\end{abstract}

In 1815, the English novelist Jane Austen published Emma, in which she wrote that boarding schools were 'where a reasonable quantity of accomplishments were sold at a reasonable price, and where girls might be sent to be out of the way, and scramble themselves into a little education, without any danger of coming back prodigies'. Yet Austen's contemporary, educator and promoter of science, Margaret Bryan, would have taken offense at such a trite assessment of her own schools, where the sciences were taken seriously in an attempt to educate young girls. Bryan provided more than a 'reasonable quantity of accomplishments' in her schools and works, and despite her more modest contributions in science and astronomy, she raised awareness of the necessary education

Voula Saridakis, 'For 'the present and future happiness of my dear Pupils': The Astronomical and Educational Legacy of Margaret Bryan', eds. Nicholas Campion and Rolf Sinclair, Culture and Cosmos, Vol. 16 nos. 1 and 2, 2012, pp. 241-253.

www.CultureAndCosmos.org 
242 For 'the present and future happiness of my dear Pupils':

The Astronomical and Educational Legacy of Margaret Bryan

young girls should receive in the sciences, and astronomy in particular. Previous historians have discussed Bryan's work without much emphasis on her astronomical and educational contributions. This paper assesses both her astronomical and educational contributions in more detail and places them in the larger context of women's participation in science in the late eighteenth and early nineteenth centuries.

Margaret Bryan (born c. 1760) was one of the most famous educators of science and astronomy in the late eighteenth and early nineteenth centuries. Not much is known about her personal life, and we have to rely on 'Dedications' and 'Prefaces' in her works to find out more about her. Her husband, a 'Mr Bryan' is not mentioned in any of her works, although at least one source claims he may have been Irish with military connections. ${ }^{1}$ Fortunately, we do know a little bit more about her children. She had two daughters, prominently pictured on the well-known frontispiece of her first work, A Compendious System of Astronomy, in a Course of Familiar Lectures, first published in 1797 (Figure 1). She explains that she has 'prefixed [her] portrait to these Lectures, together with [her] two dear children', so as to make a more 'lasting impression' on her students. Her daughters are also among her students, and she tells us that she rejoices 'in the titles of [both] Parent and Preceptress'.

In addition to her daughters in the frontispiece of $A$ Compendious System of Astronomy, she is also surrounded by various scientific instruments (including a telescope, armillary sphere, prism, and compass), as well as quills (she is holding one in her hand), an ink pot and some letters, one of which is signed by her dear friend and patron, Dr Charles Hutton, Professor of Mathematics at the Royal Military Academy at Woolwich. Despite these symbols of a more 'masculine world of scholarship', she still somehow 'radiates a soft domestic harmony'.

\footnotetext{
${ }^{1}$ Patricia Phillips, The Scientific Lady: A Social History of Woman's Scientific Interests, 1520-1918 (London: Weidenfeld and Nicolson, 1990), p. 177. According to a recent poster of famous UK women astronomers promoted by the University of Warwick and the Royal Astronomical Society, Mr. Bryan was a schoolmaster.

2 Margaret Bryan, 'Dedication' in A Compendious System of Astronomy in a Course of Familiar Lectures (London: Leigh and Sotheby and G. Kearsley, 1797), p. iii; and Margaret Bryan, 'Address to my Pupils' in Lectures on Natural Philosophy (London: Thomas Davison and George Kearsley, 1806).

3 Patricia Fara, Pandora's Breeches: Women, Science \& Power in the Enlightenment (London: Pimlico, 2004), p. 207.
} 


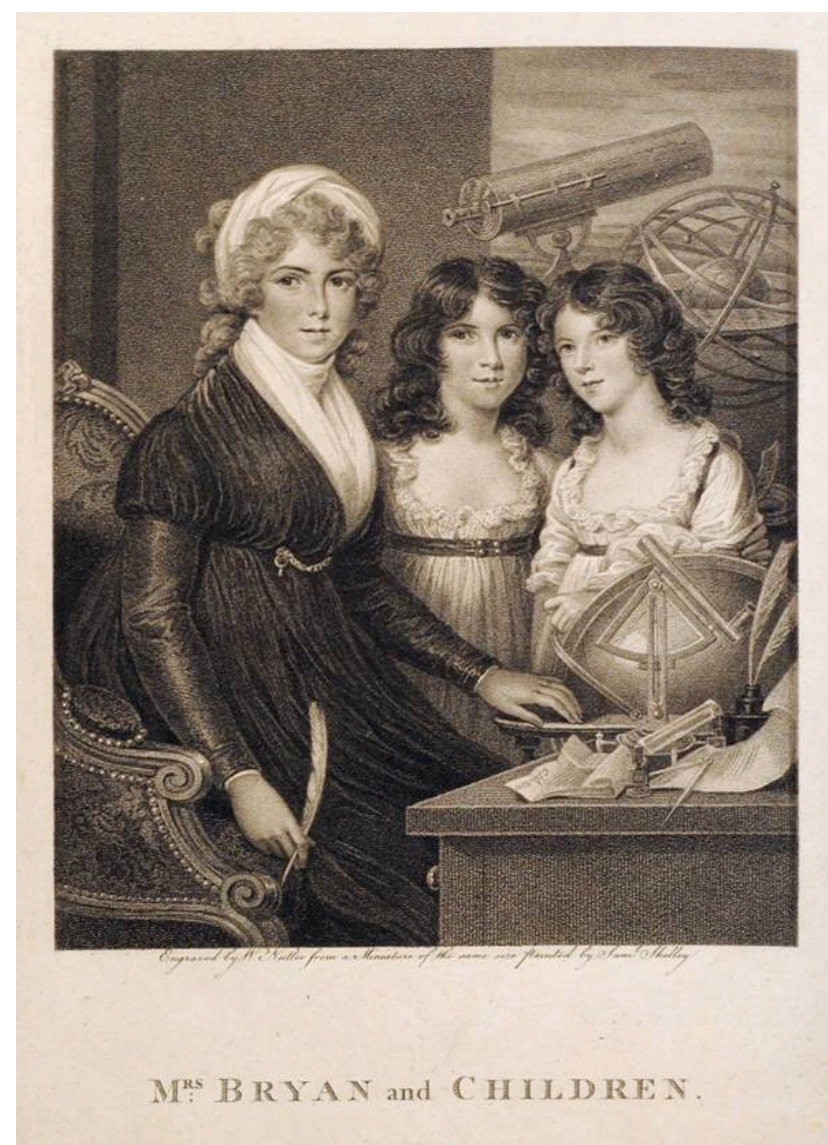

Figure 1. Margaret Bryan, frontispiece to A Compendious System of Astronomy in a Course of Familiar Lectures (London: Leigh and Sotheby and G. Kearsley, 1797) (Courtesy of the Webster Institute for the History of Astronomy, Adler Planetarium and Astronomy Museum)

In the frontispiece to her second work, Lectures on Natural Philosophy, published in 1806 and dedicated to the young Princess Charlotte of Wales, there is an absence of any scientific ornamentation, perhaps as if to affirm that it is no longer needed to help legitimize her work (Figure 2). 
244 For 'the present and future happiness of my dear Pupils':

The Astronomical and Educational Legacy of Margaret Bryan

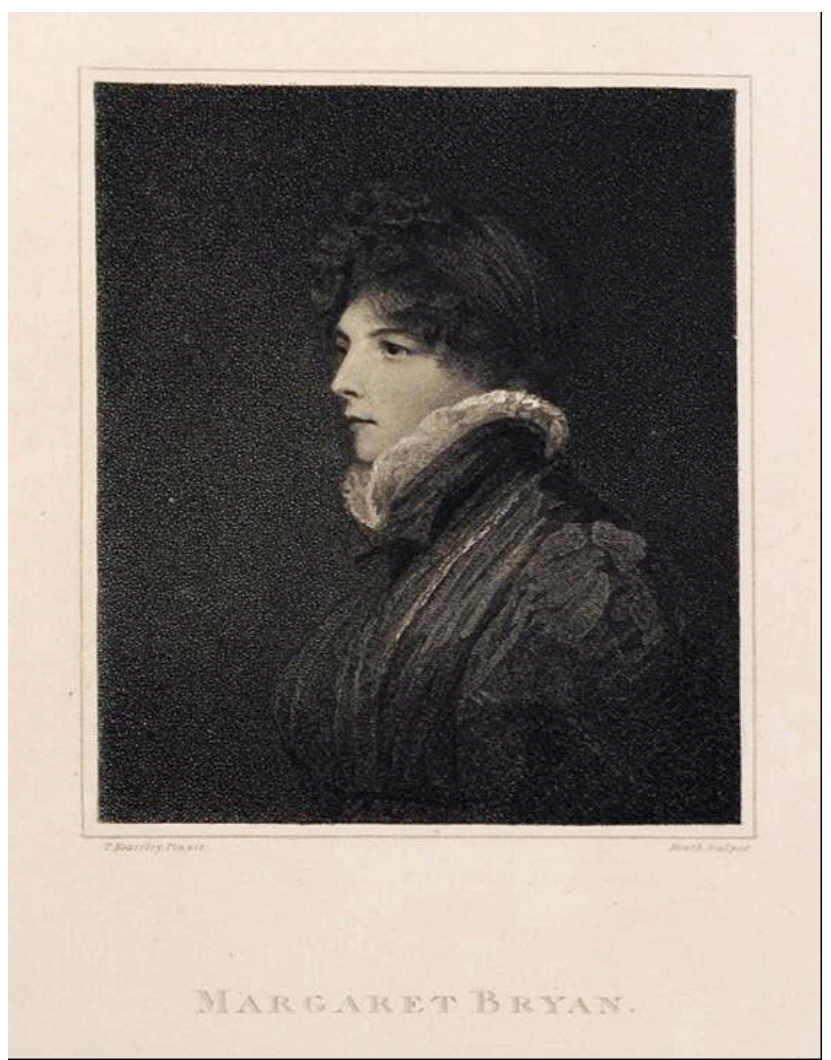

Figure 2. Margaret Bryan, frontispiece to Lectures on Natural Philosophy (London: Thomas Davison and George Kearsley, 1806) (Courtesy of the Webster Institute for the History of Astronomy, Adler Planetarium and Astronomy Museum).

In fact, Bryan's confidence increases with each of her works, and she even indicates how learned men in universities, astronomers, and mathematicians have approved of her 'scientific researches and mode of communicating the same'. All personal ornamentation is finally abandoned with the frontispiece to her third and final little work, $A$ Comprehensive Astronomical and Geographical Class Book of 1815, in which one finds an ornate engraving of a celestial globe.

4 Margaret Bryan, 'Preliminary' in A Comprehensive Astronomical and Geographical Class Book, for the Use of Schools and Private Families (London: Baldwin, Cradock, and Joy, 1815), pp. iii-iv.

Culture and Cosmos 
Listed in each of her first two major works are the subscribers those who put up the money to finance the publications. This includes members of the aristocracy, military, and clergy (including 'Reverend Dr Maskelyne, Astronomer Royal'); various Oxford and Cambridge libraries and colleges; a fair number of booksellers; book clubs (such as the Sittingbourne and Milton Book Society); and even some of her own students. While the exact number of students she had over the years is not entirely certain, she may have had as many as 150 throughout her career. ${ }^{5}$ Between the 1790s and 1810s, she opened three boarding schools for girls: one was in Bryan House, Blackheath, London, another was at 27 Lower Cadogan Place near Hyde Park corner, and the third at Margate, a seaside town in the county of Kent.

Taken together, Bryan's works give an excellent insight into the level of her knowledge and skills in astronomical theory, observation, and instrumentation. She even informs us in the 'Preface' to her Lectures on Natural Philosophy that she had fifteen years of experience before the publication of her first work: eight years of study followed by seven years' practical experience. ${ }^{6}$ In her Compendious System of Astronomy, she admits that her writing is not original, but nonetheless emphasizes that she has undertaken this work so as to educate young people and adds that she 'craves the indulgence of a discriminating public'. ${ }^{7}$ The lectures, she reminds us, were originally intended for her students, not for the public. While some may argue that the subjects she describes are 'too sublime for female introspection', Bryan tells us that these are prejudices only and that the female intellect can, in fact, grasp her work, even if women are 'enfeebled by female attire'. ${ }^{8}$ Yet Bryan forewarns that she does not want to confuse her students with theories and mathematics 'too profound for [their] contemplation'. ${ }^{9}$ Instead, she relies on visual demonstrations, explanations, and diagrams that even she admits are more useful learning tools than abstract theory and explanation alone.

In all three works, she promotes a Newtonian system and incorporates Newtonian optics, describes the path of light through convex

\footnotetext{
${ }^{5}$ Nicholas Hans, New Trends in Education in the Eighteenth Century (London: Keegan Paul, 1951), p. 204.

${ }^{6}$ Bryan's volume, Lectures on Natural Philosophy is subtitled 'Philosophy: The Result of Many Years' Experience of the Facts Elucidated'.

${ }^{7}$ Bryan, Compendious System of Astronomy, 'Preface', p. vii.

${ }^{8}$ Bryan, Compendious System of Astronomy, 'Preface', p. ix.

${ }^{9}$ Bryan, Compendious System of Astronomy, 'Preface', p. ix and p. 104.
} 
246 For 'the present and future happiness of my dear Pupils':

The Astronomical and Educational Legacy of Margaret Bryan

lenses, discusses the differences between reflectors and refractors, lists the constellations, explains the principles of navigation and geography, and demonstrates the truth of the Copernican system over the 'absurdity' of the Ptolemaic. She lists the contributions of individuals such as Thales, Copernicus, Galileo, 'the immortal Newton' (several times), Huygens, 'Doctor Halley', 'Mr Flamsteed', and 'Doctor Herschel'. ${ }^{10}$ Uranus is referred to as the 'Georgium Sidus' (or Herschel) in honor of Herschel's recent discovery. ${ }^{11}$ In addition to astronomy and optics, her Lectures on Natural Philosophy also contains material on subjects such as mechanics, mechanical properties of air, pneumatics and acoustics, water and hydrostatics, magnetism, and electricity. Her books include a series of astronomical and geographical problems such as 'how to find the longitude and latitude of places on earth' or 'of the fixed stars'; 'having taken by an astronomical quadrant the height of the sun on a given day at a given latitude, to find the hour of the day'; and, 'to find by the altitude and bearing of a star at a given latitude the hour of the night'. ${ }^{12}$

Numerous plates throughout her works (several of which she drew herself) are of various geographical or astronomical principles, maps, or instruments. One of these instruments is a quadrant for measuring relative sizes and distances, and she carefully describes to her students in great detail the uses of quadrants. On telescopes, she notes that there are two kinds, refracting and reflecting, explaining that 'the former do very well for terrestrial objects, but the latter are better adapted to celestial observations' ${ }^{13}$ She even recommends to her readers that they purchase a telescope such as the one represented in Fig. 8, Plate XV from her Compendious System of Astronomy (Figure 3). This 2-foot brass reflector had been made by W. and J. Jones of Holborn, and Bryan much preferred it to the $2 \frac{1}{2}$-foot achromatic refractor she formerly owned. While reliable, this instrument was not intended for serious astronomical research and observation, but Bryan admits that 'for the common

\footnotetext{
${ }^{10}$ Bryan, Compendious System of Astronomy, pp. 47-8.

${ }^{11}$ See for example Bryan, 'A View of the Solar System' in Compendious System of Astronomy, pp. 278-79; and Bryan, 'Characters of Bodies Belonging to the Solar System' in Lectures on Natural Philosophy, p. 295.

${ }^{12}$ See for example Bryan, Comprehensive Astronomical and Geographical Class Book, pp. 36, 80, 94.

${ }^{13}$ Bryan, Compendious System of Astronomy, p. 16.
} 
purposes of celestial observation, it is the best [telescope] of any within [her] knowledge'. ${ }^{14}$

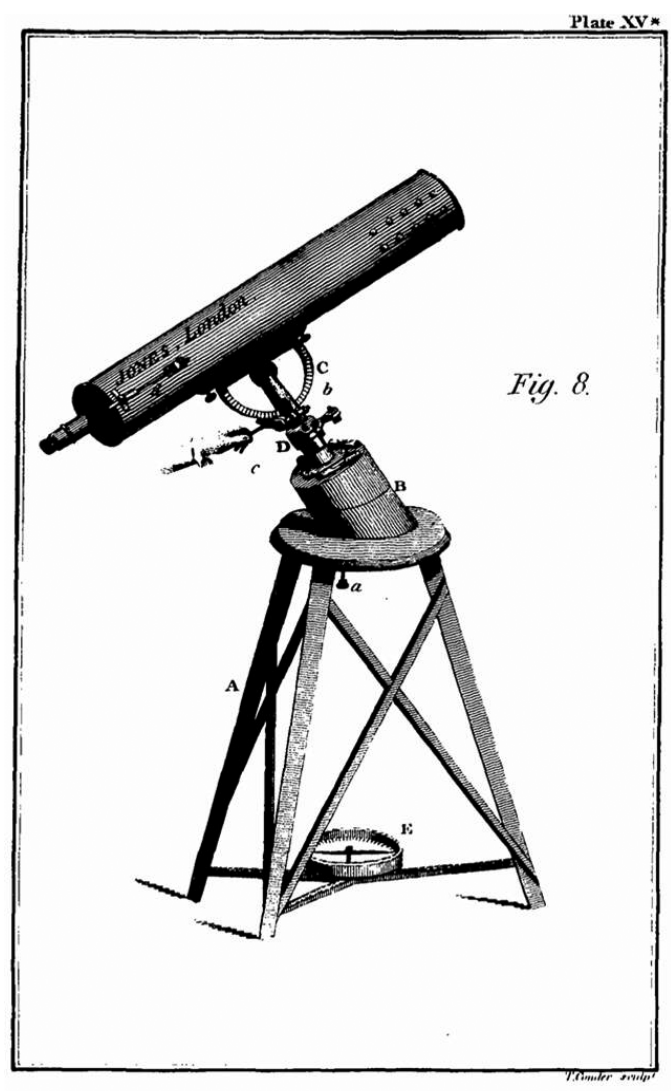

Figure 3. Fig. 8, Plate XV from Bryan's A Compendious System of Astronomy in a Course of Familiar Lectures (London: Leigh and Sotheby and G. Kearsley, 1797) (Courtesy of the Webster Institute for the History of Astronomy, Adler Planetarium and Astronomy Museum)

What is unusual about Bryan's serious investigations into the sciences and science education, is that she was able to 'fly under the radar' of criticism and scorn that usually came from scientists and society itself for a woman daring to educate young girls in the sciences, even if it was at an introductory level. It appears that she was able to avoid such derision because she based her works on two overarching objectives. First, she

${ }^{14}$ Bryan, Compendious System of Astronomy, p. 242. 
248 For 'the present and future happiness of my dear Pupils':

The Astronomical and Educational Legacy of Margaret Bryan

repeatedly indicates in her works the purpose for which they were written, and this is neatly encapsulated in the following statement from Lectures on Natural Philosophy:

I present this work on Natural Philosophy; which was originally written, and is principally intended, for the instruction and improvement of my pupils in the knowledge of physics: to impress them with a just sense of the attributes of the Deity; and thus, by unequivocal deductions, to strengthen and confirm their moral and religious principles. ${ }^{15}$

Understanding nature gives us insight into the profound wisdom, exquisite contrivance, and extensive benevolence of the Creator, in the formation, endowment, beauty, and usefulness of his works'. ${ }^{16}$ In this, she was inspired by natural theologian William Paley whose watchmaker analogy implies that a design needs a designer; therefore she implores the reader to 'cull the sweets of religion, as you rove through the flowery paths of Natural Philosophy'. ${ }^{17}$

Bryan's acceptance by society is also closely tied to her second objective, namely to 'strengthen' and 'confirm' the 'moral principles' of 'the female character'. ${ }^{18}$ She tells us to 'consider [the lessons], not merely as infusions of science, but also, and more particularly, as leading to all that is lovely, dignifying and noble', and adds, 'let my tender solicitude be repaid with knowing...that I have been instrumental in fixing your character'. ${ }^{19}$ In her 'Concluding Address to my Pupils' from Lectures on Natural Philosophy, she lists her expectations of the 'moral duties...of female life - as children, sisters, friends, wives, mothers and associates' ${ }^{20}$ Her sweeping advice continues in more detail:

Be just in your thoughts, words and actions; - prudent in the arrangement of your affairs; - temperate in your wishes and

\footnotetext{
${ }^{15}$ Bryan, Lectures on Natural Philosophy, 'Preface',

${ }^{16}$ Bryan, Lectures on Natural Philosophy, p. 1.

${ }^{17}$ Bryan, Lectures on Natural Philosophy, 'Address to My Pupils'.

${ }^{18}$ Bryan, Lectures on Natural Philosophy, 'Preface'.

${ }^{19}$ Bryan, Lectures on Natural Philosophy, 'Address to My Pupils'.

${ }^{20}$ Bryan, Lectures on Natural Philosophy, 'Concluding Address to My Pupils', p. 289.
} 
enjoyments; - patient in bearing injuries, and resigned under all the dispensations of Providence. . . As wives, consider the solemn oath pledged before God, and strictly obey its mandates. Let cheerful acquiescence evince your affection towards your husband... In society, be unassuming, obliging, charitable...Cultivate a cheerful disposition...but let your gaiety be tempered by sedate thought and reflection... Avoid gossiping or talking of other people's affairs; for this practice bespeaks a weak and vacant mind, and derogates from the modesty, delicacy and refinement of the female character. ${ }^{21}$

The inspiration and success for Bryan as a female educator of young ladies in the sciences stemmed from her twin devotions of promoting both God and female domesticity - in fact, she even celebrated domesticity. Bryan's conservative attitude, modest demeanor, and overall respectability tipped the balance in her favour and she was well-respected for her work. ${ }^{22}$

Bryan's work on a side project serves as an indication of the respect others had for her intellect and knowledge, specifically in astronomy. In 1815, she edited a popular English board game called Science in Sport, or the Pleasures of Astronomy, a New Game. Revised and Approved by Mrs. Bryan, of Blackheath, printed for Edward Wallis in London (Figure 4). ${ }^{23}$ This is an engraved playing board that could be folded up and stored neatly until needed.

\footnotetext{
${ }^{21}$ Bryan, Lectures on Natural Philosophy, 'Concluding Address to My Pupils', pp. 290.

${ }^{22}$ As Marina Benjamin concludes, 'Paradoxically then, women, by remaining within the accepted bounds of femininity, were able simultaneously to extend them', in 'Elbow Room: Women Writers on Science, 1790-1840' in Marina Benjamin (ed.), Science and Sensibility: Gender and Scientific Enquiry, 17801945 , pp. 40, 42. Bryan later appears as an 'authority' in John Lathrop's, A Compendious treatise on the Use of Globes \& Maps; compiled from the works of Keith, Ferguson, Adams, Hutton, Bryan, Goldsmith, and other eminent Authors; Being a plain and Comprehensive Introduction to the practical Knowledge of Geography and Astronomy (Boston: Wells and Lilly and J.W. Burditt, 1821).

${ }^{23}$ This board game is discussed in greater detail in the article by Melanie Keene, 'Playing among the stars' in Science in Sport, or the Pleasures of Astronomy (1804)', History of Education, Vol. 40, no. 4 (2011): pp. 521-42.
} 
250 For 'the present and future happiness of my dear Pupils':

The Astronomical and Educational Legacy of Margaret Bryan

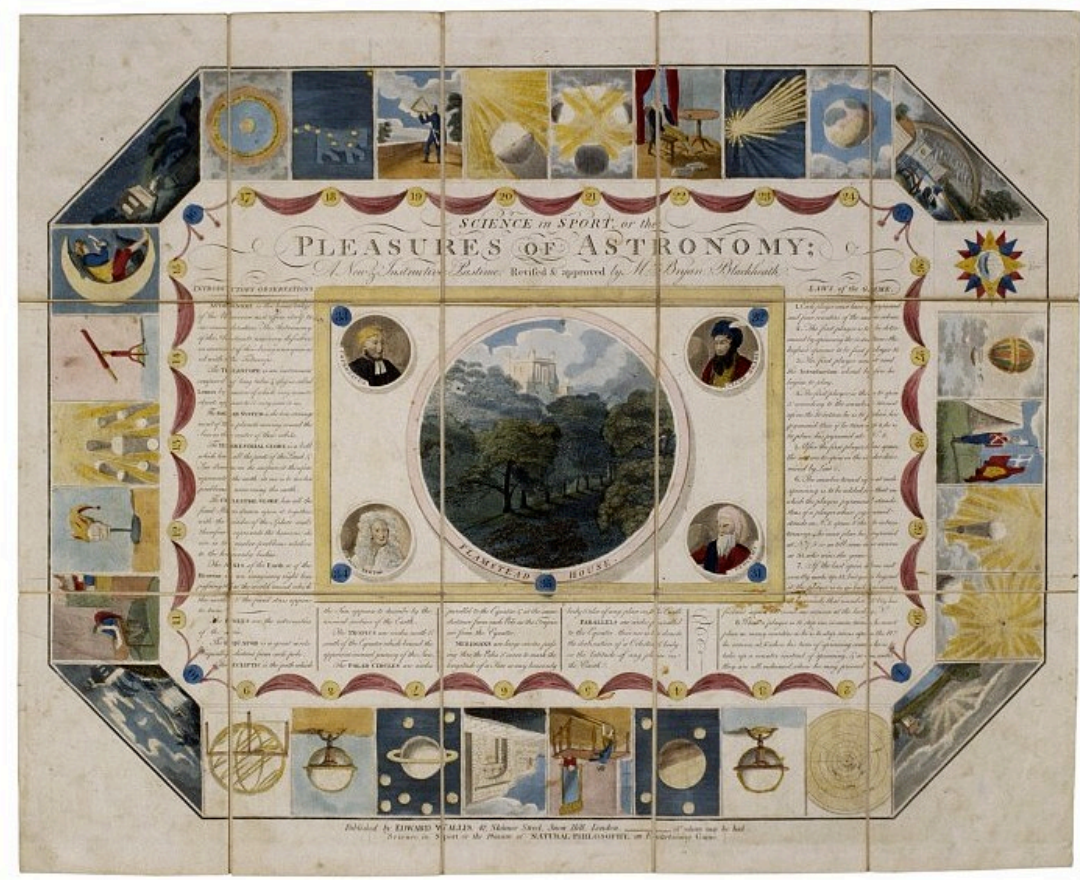

Figure 4. The 1815 reissue of the game, 'Science in Sport or the Pleasures of Astronomy'. This game was first published by John Wallis in 1804. Hand-coloured and mounted on linen (Courtesy of the Victoria and Albert Museum of Childhood, Bethnal Green, London)

Players are required to race around the board which has thirty-five squares on it with various astronomical people, places, and instruments. Players spin a teetotum (a top with numbers on it) to determine the number of spaces they need to move. The object of the game is to get to the middle first, the location of Flamsteed House, at which point the lucky player wins the game and is crowned 'Astronomer Royal' (and gets to spin first on the next game). Landing on certain spaces incurs rewards or penalties. If a player lands on space No. 14 with the telescope, for instance, the player must correctly explain its use or miss two turns. If one lands on space No. 15 the 'man in the moon', that player must then move back to space No. 13 'the phases of the moon' and re-read the correct description of the moon's phases. The game also promotes moral lessons such as diligence - if a player lands on space No. 6 'the county gaol', the instructions read, 'This is a place for those who attend to the 
motions of billiard balls, more than to the motions of planets. However hard you think your case, Stay here till someone takes your place'. ${ }^{24}$ Likewise, if a player lands on the space with the studious boy (No. 11), he or she is rewarded by getting another turn. However, the player who lands on space No. 12 with the 'blockhead' boy automatically loses the game. While it is interesting that Margaret Bryan played an important role in the reworking of this game, what is even more remarkable is that the game itself mirrors the twin objectives of educational and moral lessons found in Bryan's works, and one has to wonder at the extent of her influence in 'revising' this edition of the game.

Despite the simplification of astronomical theory, the uncomplicated explanations of observation and instrumentation, and even the amusing side project, we begin to realize the extent of Bryan's knowledge, her familiarity with instruments, and that she did, indeed, perform many of her own observations - this was no armchair schoolmarm who simply regurgitated the work of others. The desire to cultivate new knowledge and observations of the heavens, for instance, appears in a letter she wrote to William Herschel (whom she had apparently met at least once) on 3 October 1811 asking for his observations in tracking the comet of 1811 (which he had observed with better instruments):

I once had the honour of being introduced to you by my friend Dr Hutton; and was most delightfully \& politely entertained by you at Slough, and was particularly gratified by perceiving you had afforded me the distinction of placing my portrait in your study: I mention this circumstance that you may recollect who I am. I avail myself of the obliging attention I then received; to solicit your kindnesse to communicate the result of your observations on the present Comet, so far as relates to its apparent path and its situation in respect to the Sun and our Earth. I have been for some time past taking its right ascension, and declination; and by comparing them, with the same of the Sun; I conceive that it is departing from the Sun and the Earth;

\footnotetext{
${ }^{24}$ This rule (as well as all the others) is found in the instructions booklet, Science in Sport, or the Pleasures of Astronomy, a New Game. Revised and Approved by Mrs. Bryan, of Blackheath (London: Edward Wallis, 1815). This booklet along with the folded game board neatly fitted into a portable wallet made specifically for the game.
} 
252 For 'the present and future happiness of my dear Pupils':

The Astronomical and Educational Legacy of Margaret Bryan

but I am not supplied with the means of more accurate observation. ${ }^{25}$

While not original in her research, Bryan practiced what she preached, and shared her knowledge with her students and readers. Certainly, Bryan's work goes beyond the spiritual and domestic applications of science. It involves the practical applications and knowledge of astronomy, geography, and other scientific subjects. It was serious science for beginners that required an understanding of scientific terminology and a concrete understanding of the use and application of instruments. Introductory science by popularisers and educators in this period did not necessarily mean that the serious content of science was ignored. ${ }^{26}$

Unfortunately, Bryan's name is often overlooked in the history of science because she does not stand out as a pioneer in theory, experiment, or discovery. She is often categorized as a populariser, and even worse, her career is overshadowed by her well-known contemporary Caroline Herschel's. Bryan's success rests in the dissemination of science, however, which stresses the utility of knowledge in general and especially for understanding the works of the Creator and for cultivating moral virtues. By being able to do all that in a modest and, oftentimes, apologetic manner, Bryan was able to successfully drive a 'wedge' into public life, even if that was not her intention. She maintained her own virtue and credibility by upholding traditional female virtues. The small number of women in the history of science who achieved that level of influence and authority were able to expand their power beyond the family and household, and were not only accepted, but usually commended for their efforts.

Increasingly throughout the nineteenth century, British women interested in astronomy took advantage of new opportunities open to

\footnotetext{
${ }^{25}$ Letter 13.B.162 of the William Herschel Correspondence, Royal Astronomical Society. Bryan is referring to the very bright and visible comet of 1811 which was at its brightest in October, when she wrote the letter. It does not appear that Herschel ever responded to her letter.

${ }^{26}$ Although, as Michael R. Lynn argues, removing the mathematics and basing courses on more entertaining observations and experiments 'does imply that these courses frequently were set at an introductory level', Popular Science and Public Opinion in Eighteenth-Century France (Manchester and New York: Manchester University Press, 2006), p. 49.
} 
them including: attending classes at major universities (they would eventually have the opportunity to attend the new women's colleges); doing routine work at both public and private observatories; participating in new societies such as the British Astronomical Association and the British Association for the Advancement of Science; and going on solar eclipse expeditions. ${ }^{27}$ Perhaps Bryan never considered the possibility of such future goals for women interested in astronomy. Nevertheless, her approach opened doors for young girls who were interested in a serious scientific education thereby making introductory science an intellectually, socially, and morally acceptable endeavour for women.

\section{Acknowledgments}

I would like to thank the group of individuals and institutions that helped make this paper possible: Nicholas Campion and organizers of INSAP VII in Bath for the invitation to present an earlier version of this paper at the meeting; Devon Pyle-Vowles, Jill Postma, and the rest of the staff of the Webster Institute for the History of Astronomy at the Adler Planetarium; Catherine Howell, Collections Officer at the Victoria and Albert Museum of Childhood in Bethnal Green, London; and, the late Peter Hingley, former Librarian of the Royal Astronomical Society, London. I especially want to thank my Richter Scholar, Keziah Tetteh, who in the summer of 2008 did an outstanding job researching material on Margaret Bryan at Lake Forest College. Finally, my deepest gratitude goes to Constantine Alexandrakis for providing the opportunities that make papers like this one possible.

27 These opportunities for British women astronomers are described at great length in Peggy Aldrich Kidwell, 'Women Astronomers in Britain, 1780-1930', Isis, Vol. 75, no. 3 (1984): pp. 534-46. 